\title{
PENGARUH DEBT EQUITY RATIO (DER), EARNING PER SHARE (EPS) dan ECONOMY VALUE ADDED (EVA) TERHADAP HARGA SAHAM PADA PERUSAHAAN MANUFAKTUR YANG TERDAFTAR PADA BURSA EFEK INDONESIA TAHUN 2011-2015
}

\author{
Imam Hidayat \\ Email : imam_accounting@yahoo.com \\ Universitas Muhammadiyah Tangerang
}

\begin{abstract}
This study aims to analyze the effect of Debt Equity Ratio (DER), Earning Per Share (EPS) and Economy Value Added (EVA) on Stock Prices. The design of this study is causality with the unit of analysis being companies from samples taken by purposive sampling technique in the population IDX registered companies that enter into Manufacturing Companies, with the help of SPSS 23.0 program and test their hypotheses using the t test. The results of the manufacturing company group are: 1. DER does not have a negative and significant effect on stock prices; 2. EPS does not have a negative and significant effect on stock prices; 3. EVA has a positive and significant effect on stock prices; 4. DER, EPS and EVA have a positive and significant effect on stock prices
\end{abstract}

\begin{abstract}
ABSTRAK
Penelitian ini bertujuan untuk menganalisis pengaruh Debt Equity Ratio (DER), Earning Per Share (EPS) dan Economy Value Added (EVA) terhadap Harga Saham, Desain penelitian ini bersifat kausalitas dengan unit analisisnya adalah perusahaan dari sampel yang diambil dengan teknik purposive sampling pada populasi perusahaan terdaftar BEI yang masuk kedalam Perusahaan Manufaktur, dengan bantuan program SPSS 23.0 dan uji hipotesisnya menggunakan uji t. Hasil dari kelompok Perusahaan manufaktur yaitu : 1 . DER tidak berpengaruh negatif dan signifikan terhadap harga saham; 2. EPS tidak berpengaruh negatif dan signifikan terhadap harga saham; 3. EVA berpengaruh positif dan signifikan terhadap harga saham; 4. DER, EPS dan EVA berpengaruh positif dan signifikan terhadap harga saham
\end{abstract}

Kata kunci : $\quad$ Debt Equity Ratio (DER), Earning Per Share (EPS) dan Economy Value Added (EVA), Harga Saham. 


\section{PENDAHULUAN}

Harga saham merupakan harga yang dibentuk dari interaksi para penjual dan pembeli saham yang dilatar belakangi oleh harapan terhadap profit perusahaan. Dalam aktivitas di pasar modal, harga saham merupakan faktor yang sangat penting dan harus diperhatikan oleh investor dalam melaksanakan investasi, karena harga saham menunjukkan nilai suatu perusahaan. Semakin tinggi nilai harga saham semakin tinggi pula nilai perusahaan tersebut dan juga sebaliknya. Harga saham di bursa ditentukan oleh kekuatan pasar, yang berarti harga saham tergantung dari kekuatan permintaan dan penawaran. Kondisi permintaan atau penawaran atas saham yang fluktuatif tiap harinya akan membawa pola harga saham yang fluktuatif juga. Pada kondisi dimana permintaan saham lebih besar, maka harga saham akan cenderung naik, sedangkan pada kondisi dimana penawaran saham lebih banyak maka harga saham akan menurun (Saptadi, 2007).

\section{Grafik Pergerakan Harga Saham Jakarta Composite Stock Price Index dan Trading Volume}

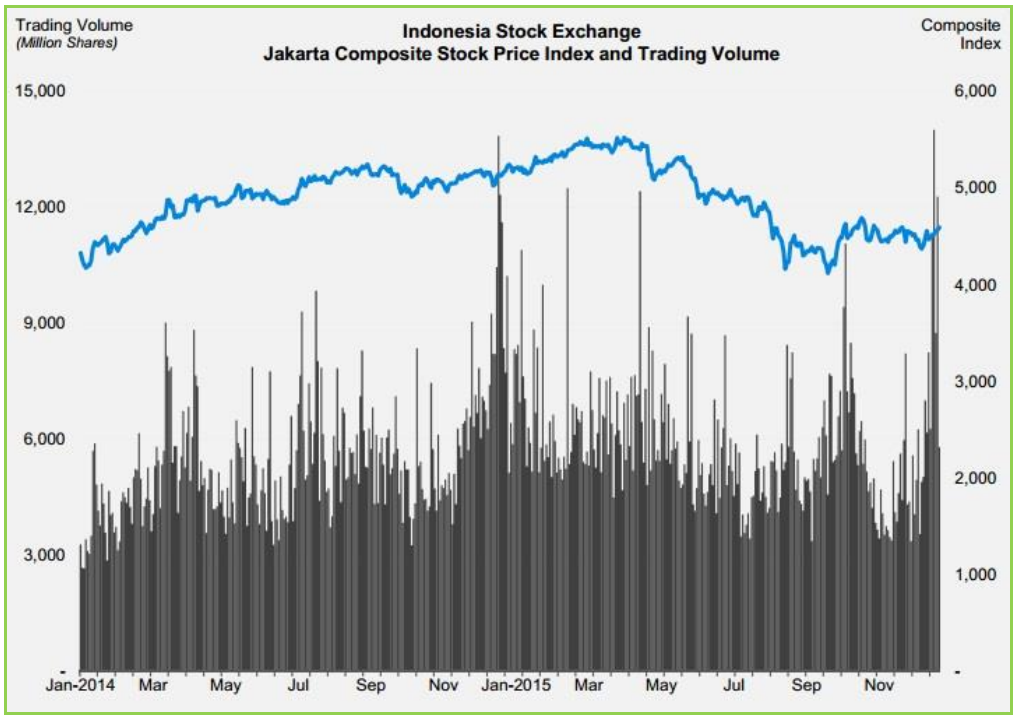

Sumber: www.idx.co.id 
Berdasarkan grafik 1 di atas terlihat naik turunnya harga saham gabungan di Indonesia selalu mengalami fluktuasi yang selalu tergantung pada supplies dan deman pasar atas pertimbangan yang rasional dari investor baik secara fundamental maupun teknikal. Antara lain faktor dari informasi laporan keuangan yaitu informasi laporan keuangan meliputi Neraca, Laporan Laba Rugi, Laporan Perubahan Modal dan Laporan Arus Kas yang dapat dijadikan dasar dalam pengambilan keputusan ekonomi, karena informasi ini menunjukkan prestasi perusahaan pada periode tersebut.

Melihat peranan informasi menjadi penting bagi investor dalam pengambilan keputusan. Informasi mengenai perusahaan dapat diperoleh dari pihak internal maupun eksternal perusahaan. Eksternal berhubungan dengan kondisi perekonomian, tingkat suku bunga, kebijakan pemerintah dan lain-lain. Sedangkan internal dapat berasal dari laporan keuangannya. Dari laporan keuangan kita dapat memprediksi kemampuan perusahaan pada masa yang akan datang. Agar pihak-pihak yang mempunyai kepentingan tersebut dapat mengerti mengenai keadaan perusahaan maka kita perlu menganalisa laporan keuangan sehingga dapat menghasilkan informasi yang diinginkan.

\section{Perumusan Masalah}

1. Apakah Debt Equity Ratio (DER) secara parsial berpengaruh terhadap harga saham ?

2. Apakah Earning Per Share (EPS) secara parsial berpengaruh terhadap harga saham?

3. Apakah Economy Value Added (EVA) secara parsial berpengaruh terhadap Harga Saham?

4. Apakah Debt Equity Ratio (DER), Earning Per Share (EPS) dan Economy Value Added (EVA) secara simultan berpengaruh terhadap Harga Saham? 


\section{TINJAUAN PUSTAKA}

\section{Harga Saham}

Menurut Pandji dan Piji (2003:58) harga saham dapat dibedakan menjadi 3 yaitu :

a) Harga Nominal : Harga yang tercantum dalam sertifikat saham yang ditetapkan oleh emiten untuk menilai setiap lembar saham yang dikeluarkan. Besarnya harga nominal membebankan arti penting saham karena deviden minimal biasanya ditetapkan berdasarkan nilai nominal.

b) Harga saham perdana : Harga ini menerapkan pada waktu harga saham tersebut dicatat di bursa efek. Harga saham perdana biasanya ditetapkan oleh penjamin emisi (underwriter) dan emiten. Dengan demikian akan diketahui berapa harga saham emiten itu akan dijual kepada masyarakat biasanya untuk menentukan harga saham perdana.

c) Harga pasar : Kalau harga saham perdana merupakan harga jual dari perjanjian emisi kepada investor, maka harga pasar adalah harga jual dari investor yang satu dengan investor yang lain. Harga ini terjadi setelah saham tersebut dicatatkan di bursa. Transaksi disini tidak lagi melibatkan emiten dari penjamin emisi harga ini yang disebut sebagai harga di pasar sekunder dan harga inilah yang benar-benar mewakili harga perusahaan penerbitnya, karena pada transaksi di pasar sekunder, kecil sekali terjadi negosiasi harga investor dengan perusahaan penerbit. Harga yang setiap hari diumumkan di surat kabar atau media lain adalah harga pasar.

\section{Economy Value Added (EVA)}

Economy Value Added (EVA) merupakan suatu konsep yang dikemukakan oleh G. Bennet Stewart pada tahun 1990. Konsep ini dapat berdiri sendiri tanpa perlu dibandingkan dengan perusahaan sejenis atau membuat analisa kecenderungan dengan tahun-tahun sebelumnya. 
Untuk menentukan besarnya EVA dapat dihitung dengan menggunakan rumus berikut :

\section{EVA = NOPAT- (WACC $x$ Invested Capital)}

Dimana :

NOPAT $=$ Laba operasi setelah pajak ( Net Operating Profit After Tax $)$

WACC = Biaya ekuitas rata-rata tertimbang ( Weighted Average Cost of Capital)

Invested Capital $=$ Besarnya capital yang diinvestasikan dalam aktivitas operasional

dan non operasional perusahaan.

\section{Debt Equity Ratio (DER)}

Sunjaya dan Barlian (2003), Debt to Equity Ratio merupakan kemampuan perusahaan untk melakukan pembayaran hutang sesuai dengan perjanjian berdasarkan jadual selama umur hutangnya. Dalam hutang terdapat kewajiban tetap unruk membayar bunga dan pokok pinjaman.

Sawir (2003), DER menggambarkan perbandingan hutang dan ekuitas dalam pendanaan perusahaan dan menunjukan kemampuan modal sendiri perusahaan tersebut untuk memenuhi seluruh kewajibannya. Sedangkan Brigham and Houston (2001), DER mengukur persentase dana yang disediakan dari internal company. Total hutang mencakup hutang lancar maupun hutang jangka panjang. Investor akan lebih menyukai rasiohutang yang lebih rendah, karena semakin rendah rasio ini semakin besar perlindungan terhadap kerugian investor dari peristiwa likuidasi.

$$
\text { Debt Equity Ratio }=\frac{\text { Total Debt }}{\text { Total Equity }} x 100 \%
$$

\section{Earning Per Share (EPS)}

Laba per lembar saham atau EPS merupakan rasio yang menunjukkan berapa besar keuntungan (laba) yang diperoleh investor atau pemegang saham per lembar sahamnya. EPS sama dengan deviden saham umum dibagi jumlah lembar saham umum, (Darmadji dan Hendy,2001). Sedangkan EPS menurut Sawidji (2005:102), 
Earning Per Share (EPS). Merupakan rasio antara pendapatan setelah pajak dengan jumlahsaham yang beredar. Earning Per Share (EPS) menggambarkan laba per bersih dibagi jumlah saham beredar. Laba bersih setelah bunga dan pajak.

$$
\text { Earning per Share }=\frac{\text { Laba Kotor }}{\text { Jumlah Saham Beredar }}
$$

\section{METODE PENELITIAN}

Penelitian yang digunakan dalam penelitian ini adalah penelitian kuantitatif, dimana data yang diperoleh dari sampel populasi penelitian kemudian dianalisis sesuai dengan metode statistik yang digunakan lalu diinterprestasikan

Definisi variabel operasional dari masing-masing variabel disajikan dalam tabel berikut :

\section{Definisi Operasional Variabel}

\begin{tabular}{|c|c|c|c|c|}
\hline No & Variabel & Definisi & Skala & Pengukuran \\
\hline 1 & $\begin{array}{l}\text { Debt Equity } \\
\text { Ratio (DER) }\end{array}$ & $\begin{array}{l}\text { Perbandingan antara } \\
\text { jumlah hutang dengan } \\
\text { jumlah modal }\end{array}$ & Rasio & $\mathrm{DER}=\frac{\text { Total Debt }}{\text { Total Equity }} \times 100 \%$ \\
\hline 2 & $\begin{array}{l}\text { Earning Per } \\
\text { Share (EPS) }\end{array}$ & $\begin{array}{l}\text { Perbandingan antara } \\
\text { laba bersih setelah } \\
\text { pajak dengan jumlah } \\
\text { saham yang beredar }\end{array}$ & Rasio & $\mathrm{EPS}=\frac{\text { Laba Kotor }}{\text { Jumlah Saham Beredar }}$ \\
\hline 3 & $\begin{array}{c}\text { Economy } \\
\text { Value Added } \\
\text { (EVA) }\end{array}$ & $\begin{array}{l}\text { Ukuran kinerja } \\
\text { keuangan yang } \\
\text { memperhitungkan } \\
\text { kepentingan pemilik } \\
\text { modal }\end{array}$ & Nominal & $\begin{array}{c}\mathrm{EVA}=\text { NOPAT }-(\text { WACCx Invested } \\
\text { Capital })\end{array}$ \\
\hline 4 & Harga Saham & $\begin{array}{l}\text { Harga suatu saham } \\
\text { pada akhir tahun }\end{array}$ & Nominal & Harga Saham Akhir Tahun \\
\hline
\end{tabular}




\section{Populasi}

Populasi dari penelitian ini adalah seluruh saham-saham perusahaan yang tercatat dalam perhitungan perusahaan manufaktur periode tahun 2011-2015. Dasar dari pemilihan populasi ini adalah untuk membandingkan perusahaan kategori yang mana yang paling mempengaruhi pergerakan saham dan keadaan pasar.

\section{Sampel}

Teknik pengambilan sampel yang digunakan dalam penelitian ini adalah purposive sampling, yaitu suatu teknik pengambilan sampel berdasarkan kepada karakteristik tertentu yang memiliki keterkaitan dengan karakteristik yang sudah diketahui sebelumnya atau tujuan tertentu.

\section{Daftar Perusahaan yang menjadi Sampel Perusahaan Manufaktur}

\begin{tabular}{|c|c|l|}
\hline No & Kode Emiten & \multicolumn{1}{c|}{ Nama Perusahaan } \\
\hline 1 & AALI & Astra Agro Lestari Tbk. \\
\hline 2 & ADHI & Adhi Karya (Persero) Tbk. \\
\hline 3 & ADRO & Adaro Energy Tbk. \\
\hline 4 & ANTM & Aneka Tambang (Persero) Tbk. \\
\hline 5 & ASII & Astra Internasional Tbk. \\
\hline 6 & ASRI & Alam Sutera Realty Tbk. \\
\hline 7 & BMTR & Global Mediacom Tbk. \\
\hline 8 & BSDE & Bumi Serpong Damai Tbk. \\
\hline 9 & GGRM & Gudang Garam Tbk. \\
\hline 10 & ICBP & Indofood CBP Sukses Makmur Tbk. \\
\hline 11 & INCO & International Nickel Indonesia Tbk. \\
\hline 12 & INDF & Indofood Sukses Makmur Tbk. \\
\hline 13 & INTP & Indocement Tunggal Prakarsa Tbk. \\
\hline 14 & JSMR & Jasa Marga (Persero) Tbk. \\
\hline 15 & KLBF & Kalbe Farma Tbk. \\
\hline 16 & LPKR & Lippo Karawaci Tbk. \\
\hline 17 & LSIP & London Sumatera Plantation Tbk. \\
\hline 18 & PGAS & Perusahaan Gas Negara (Persero) Tbk. \\
\hline 19 & UNTR & United Tractors Tbk. \\
\hline 20 & UNVR & Unilever Indonesia Tbk. \\
\hline Sumber & & \\
\hline
\end{tabular}

Sumber : www.idx.co.id 


\section{HASIL DAN PEMBAHASAN}

\section{Analisis Deskriptif}

\section{Descriptive Statistics}

\begin{tabular}{|c|c|c|c|c|c|}
\hline & $\mathrm{N}$ & Minimum & Maximum & Mean & Std. Deviation \\
\hline DER & 100 & -31.78 & 40.37 & 9269 & 5.27938 \\
\hline EPS & 100 & -17063713.10 & $\begin{array}{l}5473710717.0 \\
9\end{array}$ & $\begin{array}{l}541342915.93 \\
12\end{array}$ & $\begin{array}{l}1118627117.791 \\
50\end{array}$ \\
\hline EVA & 100 & $\begin{array}{l}- \\
1700318485715 \\
.86\end{array}$ & $\begin{array}{l}105836697893 \\
5.16\end{array}$ & $\begin{array}{l}- \\
3038254211.3 \\
827\end{array}$ & $\begin{array}{l}369400020492.0 \\
1990\end{array}$ \\
\hline Harga Saham & 100 & 50.000 & 390000.000 & 15954.11000 & 59975.648387 \\
\hline $\begin{array}{ll}\text { Valid } & \mathrm{N} \\
\text { (listwise) } & \end{array}$ & 100 & & & & \\
\hline
\end{tabular}

Sumber: Hasil Pengolahan Data, 2016

Berdasarkan output statistik deskriptif dari tabel diatas , dapat diketahui bahwa jumlah data yang diobservasi sebanyak 100 yang didapat dari 4 variabel penelitian, yaitu Debt Equity Ratio (DER), , Earning Per Share (EPS) dan Economy Value Added (EVA), dan Harga Saham.

\section{Uji Normalitas}

One-Sample Kolmogorov-Smirnov Test

\begin{tabular}{|ll|r|}
\hline & & Saham \\
\hline $\mathrm{N}$ & & 100 \\
Normal Parameters ${ }^{\mathrm{a}, \mathrm{b}}$ & Mean & 7,3459 \\
& Std. Deviation & 2,06082 \\
Most Extreme & Absolute &, 086 \\
Differences & Positive &, 086 \\
\multicolumn{2}{|c|}{ Negative } &,- 048 \\
Kolmogorov-Smirnov Z &, 856 \\
Asymp. Sig. (2-tailed) &, 457 \\
\hline
\end{tabular}

a. Test distribution is Normal.

b. Calculated from data.

Sumber: Hasil Pengolahan Data, 2016 
Berdasarkan hasil pengujian di tabel diatas, dapat dilihat bahwa nilai Kolmogorov-Smirnov adalah 0,856 dan besarnya nilai signifikan diatas 0.05 , dimana nilai signifikannya sebesar 0.457 . Hal ini dapat disimpulkan bahwa data terdistribusi secara normal.

Pada penelitian ini, penulis hanya menggunakan grafik normal p-p plot hasil dari penelitian menggunakan grafik normal $p$ - $p$ plot adalah sebagai berikut:

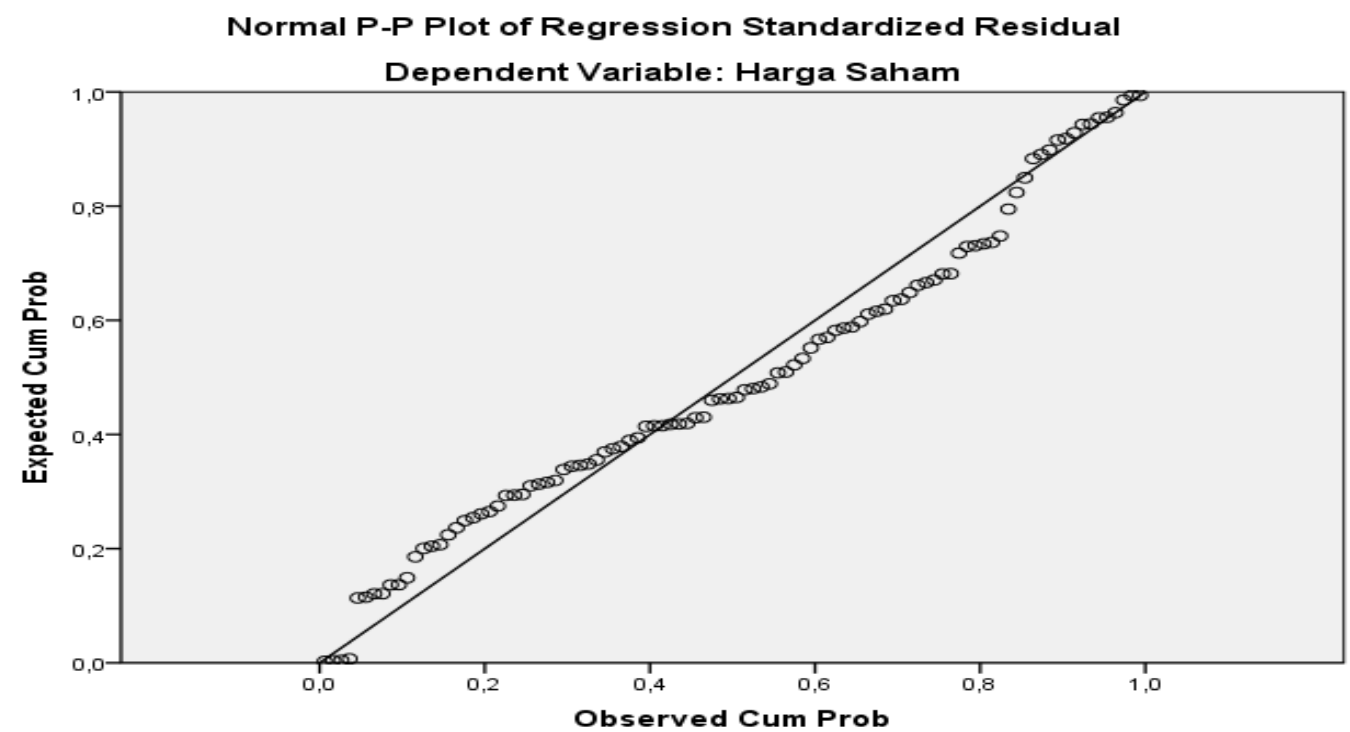

Sumber: Hasil Pengolahan Data, 2016

Dari gambar diatas, dapat dilihat bahwa titik-titik menyebar disekitar garis diagonal, yang dapat diasumsikan bahwa model regresi memenuhi asumsi normal. Sementara apabila titik-titik menyebar menjauhi garis diagonal, maka model regresi semakin menjauh dari asumsi normal.

\section{Uji Autokorelasi}

\section{Model Summary ${ }^{b}$}

\begin{tabular}{|c|c|}
\hline Model & Durbin-Watson \\
\hline 1 &, $421^{\mathrm{a}}$ \\
\hline
\end{tabular}




\section{Model Summary ${ }^{b}$}

\begin{tabular}{|c|c|}
\hline Model & Durbin-Watson \\
\hline 1 &, $421^{\mathrm{a}}$ \\
\hline
\end{tabular}

a. Predictors: (Constant), EVA, , DER, EPS

b. Dependent Variable:

Saham

Sumber: Hasil Pengolahan Data, 2016

Pada tabel 4.9 di atas, dengan menggunakan uji Durbin-Watson, menunjukan hasil nilai sebesar 0,421 , nilai ini diantara -2 dan +2 atau $-2 \leq 0,421 \leq 2$, maka dapat disimpulkan bahwa tidak terjadi otokorelasi antar variabel.

Uji Multikolonieritas

\begin{tabular}{|cc|r|c|}
\hline \multirow{2}{*}{} & \multicolumn{2}{|c|}{$\begin{array}{c}\text { Collinearity } \\
\text { Statistics }\end{array}$} \\
\cline { 2 - 4 } \multicolumn{2}{|c|}{ Model } & Tolerance & VIF \\
\hline 1 & DER &, 980 & 1,020 \\
& EPS &, 842 & 1,187 \\
& EVA &, 820 & 1,220 \\
\hline
\end{tabular}

a. Dependent Variable: Saham

Sumber: Hasil Pengolahan Data, 2016

Dari tabel diatas, dapat dilihat bahwa variabel yaitu Debt Equity Ratio (DER), Earning Per Share (EPS) dan Economy Value Added (EVA) memiliki nilai tolarance $(0,980 ; 0,842 ; 820)$ diatas 0,10 . Tidak adanya variabel bebas yang mempunyai nilai tolarance kurang dari 0,10 , berarti tidak adanya kolerasi atar variabel bebas. Hasil perhitungan nilai VIF (Variance Inflation Factor) juga menunjukan hal yang sama, di mana tidak satupun variabel independen $(1,020$; $1,187 ; 1,220)$ yang memiliki nilai lebih dari 10 , sehingga dapat disimpulkan bahwa tidak terdapat multikolinieritas antar variabel independen. Dari karakteristik diatas, dapat ditarik kesimpulan bahwa model regresi layak dipakai. 


\section{Uji Heteroskedastisitas}

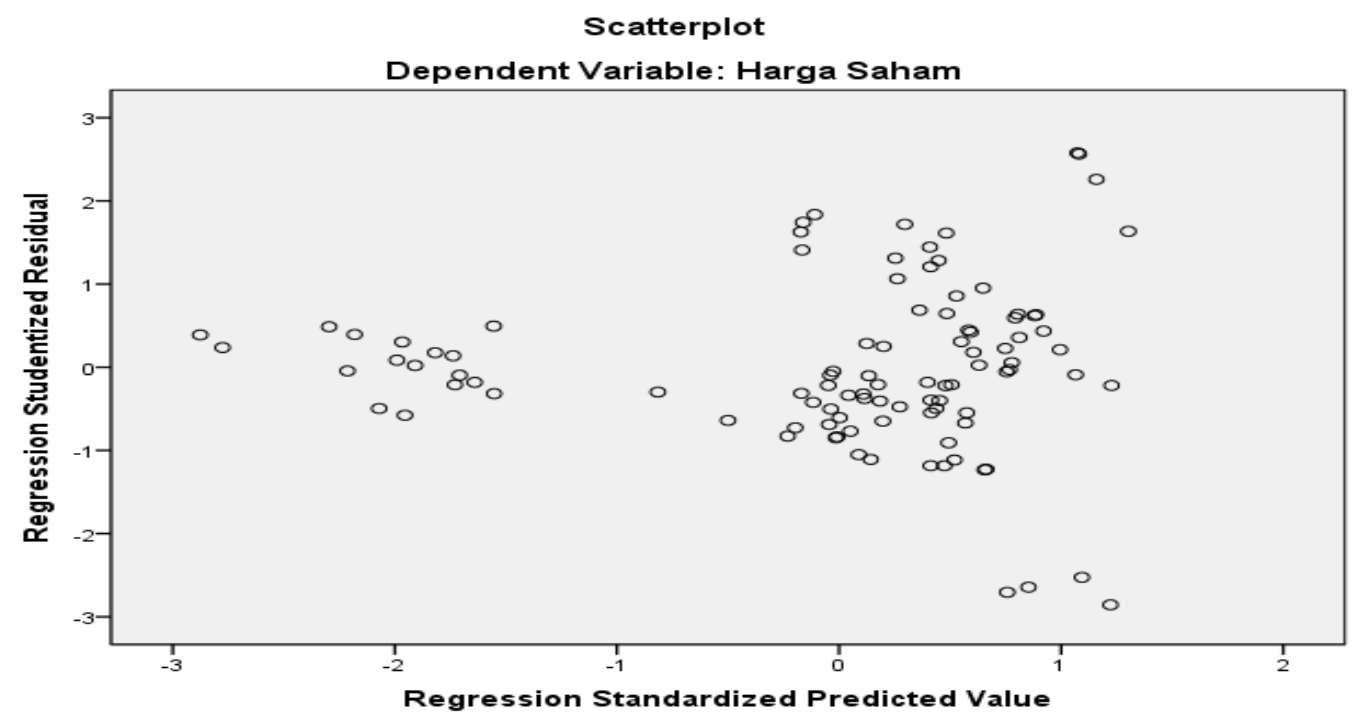

Sumber: Hasil Pengolahan Data, 2016

Dari gambar diatas terlihat hasil output uji heteroskedastisitas di atas didapatkan titik-titik menyebar di bawah angka 10 pada sumbu $\mathrm{Y}$, dan tidak mempunyai pola teratur, jadi kesimpulannya variabel yaitu Debt Equity Ratio (DER), Earning Per Share (EPS) dan Economy Value Added (EVA) di atas tidak terjadi heteroskedastisitas atau bersifat homokedastisitas.

\section{Uji t (Parsial)}

\section{Coefficients $^{\mathrm{a}}$}

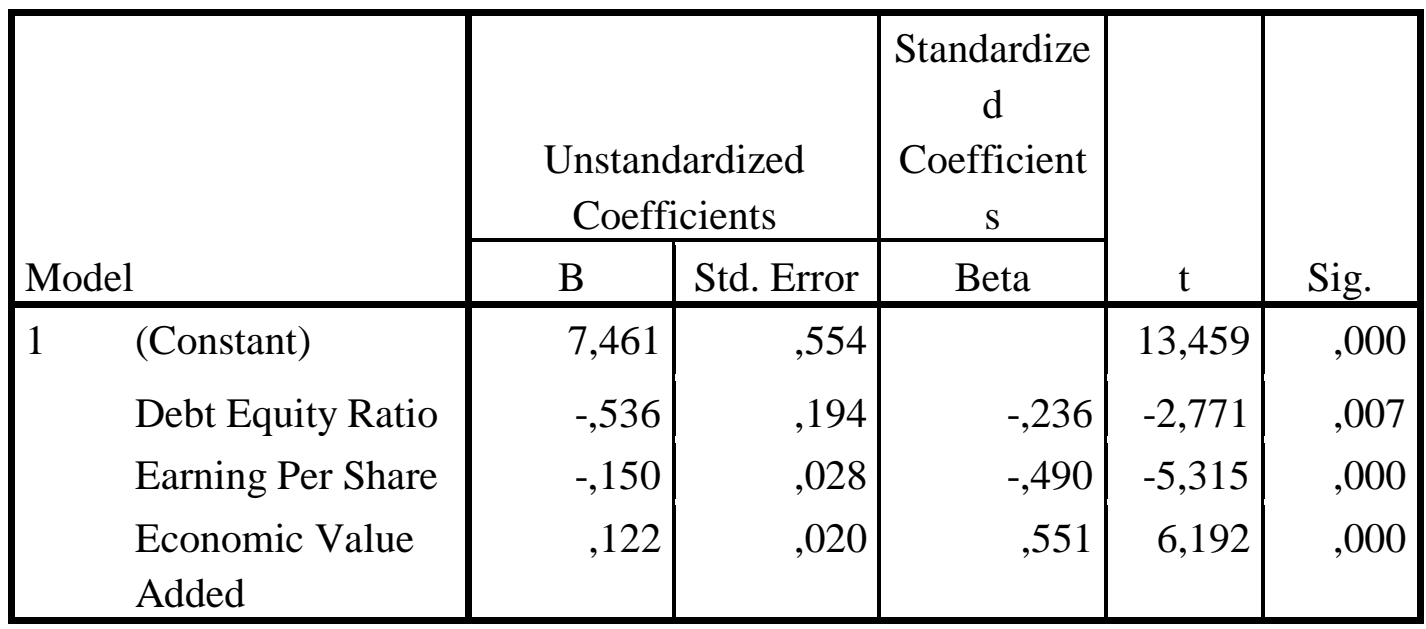


Dependent Variable: Harga Saham

Sumber: Hasil Pengolahan Data, 2016

Berdasarkan data yang disajikan pada tabel diatas, jika nilai unstandardized

coefficients kita masukan ke dalam persamaan regresi, maka akan didapat persamaan regresi I yaitu sebagai berikut :

$\mathrm{Z}=-\mathbf{0 , 2 3 6}$ DER -0,490 EPS +0,551 EVA + $\varepsilon 2$

\section{Uji F (Simultan)}

Uji Statistik F digunakan untuk menguji apakah semua variabel independen yang dimasukkan dalam model mempunyai pengaruh secara bersama-sama terhadap variabel dependen. Hasil uji F dapat dilihat dalam tabel ANOVA. Jika nilai $\operatorname{sig}<\alpha=$ 0,05 maka terdapat satu atau lebih variabel independen yang mempengaruhi variabel dependen.

\begin{tabular}{|c|c|c|c|c|c|c|}
\hline \multicolumn{7}{|c|}{ ANOVA $^{b}$} \\
\hline \multicolumn{2}{|c|}{ Model } & $\begin{array}{l}\text { Sum of } \\
\text { Squares }\end{array}$ & df & $\begin{array}{c}\text { Mean } \\
\text { Square }\end{array}$ & F & Sig. \\
\hline \multirow[t]{3}{*}{1} & Regression & 161,531 & 4 & 40,383 & 14,806 &, $000^{\mathrm{a}}$ \\
\hline & Residual & 259,104 & 95 & 2,727 & & \\
\hline & Total & 420,634 & 99 & & & \\
\hline
\end{tabular}

a. Predictors: (Constant), Economic Value Added, Debt Equity Ratio, Earning Per Share

b. Dependent Variable: Harga Saham

Sumber: Hasil Pengolahan Data, 2016

Dari tabel 4.24 dapat dilihat bahwa nilai F hitung sebesar 14,806 dengan nilai signifikansi sebesar 0.000. Karena nilai signifikansi lebih kecil dari nilai signifikansi yang telah ditetapkan, yaitu sebesar 0.05, dan Fhitung $(2,70)<$ Ftabel $(14,806)$ maka dapat disimpulkan bahwa model regresi berganda ini sangat baik untuk digunakan. Variabel independen yang terdiri dari yaitu Debt Equity Ratio (DER), Earning Per 
Share (EPS) dan Economy Value Added (EVA) dapat digunakan untuk memprediksi variabel dependen, yaitu Harga Saham.

\section{Uji Determinasi $\left(\mathbf{R}^{2}\right)$}

\begin{tabular}{|l|c|r|r|r|}
\hline Model & R & R Square & $\begin{array}{c}\text { Adjusted R } \\
\text { Square }\end{array}$ & $\begin{array}{c}\text { Std. Error of } \\
\text { the Estimate }\end{array}$ \\
\hline 1 &, $620^{\mathrm{a}}$ &, 384 &, 358 & 1,65149 \\
\hline
\end{tabular}

a. Predictors: (Constant), Economic Value Added, Debt Equity Ratio, Earning Per Share b. Dependent Variable: Harga Saham

Sumber: Hasil Pengolahan Data, 2016

Dari tabel 4.30. dapat dilihat bahwa besarnya korelasi antara variabel independen dengan variabel dependen adalah sebesar 0.620 dengan nilai pengaruh yaitu Adjusted R Square yaitu 0,358 atau 35,8\%. Ini berarti 35,8\% variabel dependen mampu dijelaskan oleh variabel independen. Dengan kata lain, 35,8\% harga saham sektor manufaktur yang terdaftar Bursa Efek Indonesia mampu dijelaskan oleh variabel yaitu Debt Equity Ratio (DER), Earning Per Share (EPS) dan Economy Value Addes(EVA) sedangkan sisanya sebesar 64,2\% dijelaskan oleh faktor-faktor lain yang tidak dijelaskan di dalam model.

\section{KESIMPULAN DAN SARAN}

1. DER tidak berpengaruh negatif dan signifikan terhadap harga saham

2. EPS tidak berpengaruh negatif dan signifikan terhadap harga saham

3. EVA berpengaruh positif dan signifikan terhadap harga saham

4. DER, EPS dan EVA berpengaruh positif dan signifikan terhadap harga saham

5. Menambah periode penelitian menjadi lebih panjang rentan periodenya.

6. Menambahkan sampel perusahaan dengan tidak hanya meneliti pada perusahaan manufaktur. 
7. Dalam penelitian selanjutnya diharapkan dapat menambah variable lain yang lebih berpengaruh terhadap nilai perusahaan misalnya profitabilitas dan ukuran perusahaan.

\section{DAFTAR PUSTAKA}

Amin Wijaya Tunggal.2005. Dasar Dasar Analisis Laporan Keuangan.Jakarta : Rineka Cipta.

Ambarita, Afnita D.2013. Skripsi : Pengaruh DER terhadap kinerja perusahaan menurut konsep EVA (studi kasus pada perusahaan rokok yang terdaftar di BEI tahun 2008-2012).

Ang, Robert. 2007. Buku Pintar Pasar Modal Indonesia (The Intelligent Guide to Indonesian Capital Market). Jakarta : Mediasoft Indonesia.

Anoraga,Pandji, dan Piji Jakarta.2006.Pengantar Pasar Modal,Edisi Revisi,Rineka Cipta,Jakarta.

Asnawi, Ssid Kelana, dan Chandra Wijaya. 2006, Metode Penelitian Keuangan, (Prosedur, Ide dan Kontrol) Yogyakarta Graha Ilmu.

Brigham, Eugene F dan Houston, Joel F. 2006. Fundamental Of Financial Management. Terj. Ali Akbar Yulianto. Jakarta : Salemba Empat.

Brigham, Eugene F dan Joel F. Houston. 2010. Dasar Dasar Manajemen Keuangan. Jakarta : Salemba Empat.

Damanik, Michael. 2008. Skripsi : Pengaruh EVA dan Analisis Fundamental Terhadap Harga Saham (Studi pada Sektor Industri Perdagangan Retail). Fakultas Ekonomi. Universitas Gunadarma. Jakarta

Darmadji Tjipto dan Hendry Fakhruddin M.2001.Pasar Modal di Indonesia, Salemba Empat,Jakarta.

Darmadji Tjipto dan Hendry Fakhruddin M.2006.Pasar Modal di Indonesia Pendekatan Tanya Jawab.Edisi Pertama.Jakarta : Salemba Empat.

Dwisona, Shindy W.2015. Skripsi : Analisis pengaruh faktor fundamental terhadap harga saham dengan ROA sebagai variabel intervening pada perusahaan LQ 45 periode 2010-2013. Universitas Diponegoro, Semarang.

Ghozali, Imam. 2009.. Aplikasi Analisis Multivariate dengan Program SPSS, Cet. IV Semarang : Badan Penerbit Universitas Diponegoro.

Hartini, Titin.,2015. Pengaruh EPS terhadap harga saham LQ-45 di BEI. 
Habibatillah, Diyanah F., 2012. Pengaruh EVA dan rasio profitabilitas terhadap harga saham pada perusahaan manufaktur yang masuk di daftar efek syariah periode 2008-2010.

Iqbal, Mohammad. 2004. Tesis : Analisa Pengaruh EVA, ROA, ROE dan EPS terhadap Harga Saham dan MVA. Pasca Sarjana Ilmu Manajemen Fakultas Ekonomi Universitas Indonesia. Jakarta.

Jogiyanto.2003.Teori Portofolio dan Nalisis Investasi Edisi Ketiga.Cetakan Pertama.Yogyakarta :BPFE.

Kusumawardani, Angrawit. 2010. Skripsi : Analisis Pengaruh EPS, PER, ROE, FL, DER, CR, ROA pada Harga Saham dan Dampaknya Terhadap Kinerja Perusahaan LQ45 yang Terdaftar di BEI Periode 2005-2009. Fakultas Ekonomi Universitas Gunadarma Jakarta.

Kieso, Donald E, Jerry J. Weygant dan Terry D. Warfield. 2012. Akuntansi Intermediate, Jilid 1 dan 2. Edisi 12. Gelora Aksara Wacana.

Martono,Agus Harjito.2007.Manajemen Keuangan.Yogyakarta :Ekonisia

Munawir.2010.Analisa Laporan Keuangan.Yogyakarta: Liberty

Octaviani, Liakerta E., 2003. Pengaruh ROA, DER dan Retention Rate terhadap EVA dengan Pertumbuhan Modal Sendiri Sebagai Variabel Intervening.

Panji, Anoraga, dkk.2006.Pengantar Pasar Modal.Jakarta : Rineka Cipta.

Ridwan.2009. Metode dan Teknik Menyusun Tesis,Alfabeta,Bandung.

Ridwan.2010.Skala Pengukuran Variabel-variabel Penelitian,Alfabeta,Bandung.

Santoso, Singih.2000. Buku Latihan SPSS Parametrik.Jakarta: PT.Elex Media Komputindo.

Sarwono, Jonathan.2006.Metode Penelitian Kualitatif dan Kuantitatif.Yogyakarta: Graha Ilmu.

Sasangko, Noer dan Nila Wulandari, 2006. Pengaruh EVA dan rasio- rasio profitabilitas terhadap harga saham. Empirika, Vol.19, No.1, Juni 2006, 64-80.

Sahudi, Slamet., 2013. Analisis pengaruh EVA dan profitabilitas terhadap EPS ( Studi kasus perusahaan Automotive dan Allied Products yang terdaftar di BEI Periode 2006-2010).

Sartono, Agus, R.2001. Manajemen Keuangan Teori dan Aplikasi. Yogyakarta: BPFE 
Sawir, Agnes.2001. EVA; Analisis Kinerja Keuangan dan Perencanaan Keuangan Perusahaan. Jakarta: PT. Gramedia Pustaka Utama.

Scoot, William R., 2009, Financial Accounting Theory, Sixth edition, Pearson Education Inc., Toronto, Canada.

Stewart, G. Bennett.1991, The Quest for Value, Harper Business, 2.

Stewart, G. Bennett.1995., Forget EPS, ROE and ROI. EVA is wahat drives stock prices. Harvard Bussiness Review, Nov-Des 1995, 20.

Sugiyono.2009. Metode Penelitian Bisnis (Pendekatan Kuantitatif, Kualitatif, Kualitatif dan $R \& D$ ). Bandung. Alfabeta.

Suad Husnan dan Enny Pudjiastuti.2007.Manajemen Keuangan,Edisi Kelima,UPP AMP YKPN,Yogyakarta.

Sunariyah.2003.Pengantar Pengetahuan Pasar Modal Jilid 2.Edisi ke 6.Jakarta :Erlangga

Sunarto dan Riduwan.2010.Pengantar Statistika.Cetakan Ketiga.Bandung:Penerbit Alfabeta.

S.Munawir.2000.Analisa Laporan Keuangan. Yogyakarta.

Young, S. David.2001. EVA and Based Management : a practical guide to implementation. McGraw-Hill, New York.

Website Bursa Efek Indonesia.www.idx.co.id.

Website Wikipedia. www.wikipedia.org

Website Yahoo Finance. www. finance.yahoo.com 